Revue d'études américaines. American Studies Journal writings / Call and Answer: Dialoguing the American West in France

\title{
Family Portraits: Representing the Contemporary North-American Family
}

\author{
Nicolas Raulin
}

\section{QpenEdition}

\section{Journals}

\section{Electronic version}

URL: https://journals.openedition.org/transatlantica/10301

DOI: 10.4000/transatlantica.10301

ISSN: 1765-2766

Publisher

Association française d'Etudes Américaines (AFEA)

\section{Electronic reference}

Nicolas Raulin, "Family Portraits: Representing the Contemporary North-American Family",

Transatlantica [Online], 2 | 2017, Online since 18 April 2019, connection on 31 January 2023. URL:

http://journals.openedition.org/transatlantica/10301 ; DOI: https://doi.org/10.4000/transatlantica. 10301

This text was automatically generated on 31 January 2023.

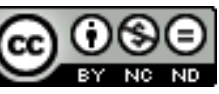

Creative Commons - Attribution-NonCommercial-NoDerivatives 4.0 International - CC BY-NC-ND 4.0 https://creativecommons.org/licenses/by-nc-nd/4.0/ 


\title{
Family Portraits: Representing the Contemporary North-American Family
}

\author{
Nicolas Raulin
}

1 The conference was organized by Sophie Chapuis (University Jean Monnet, SaintÉtienne) and Marie Moreau (University of Jean Moulin Lyon 3) and the Centre d'Études sur les Langues et les Littératures Étrangères et Comparées (CELEC). It took place at the University of Saint-Étienne, Jean Monnet on September 27th and 28th 2018. The conference was the occasion to assess the state of the contemporary American family and its ever-changing modes at a time when the reshaping of family structures coexists with a deep attachment to the traditional family unit.

\section{Panel 1: Family Performance}

2 The main theme of the first panel revolved around the onscreen representation of the American family and the way it questioned the traditional family model.

Sandra Becker (University of Groningen, Netherlands) opened the symposium by addressing the numerous TV shows from the 2000s centered around white heterosexual father figures. More than yet another product of the anti-feminist backlash, these traditional male characters should be analyzed in the troubled period of 9/11 and the economic recession but also within a continuing cycle of nostalgia where America looks to past models as a means to restore order. The analysis of two specific TV shows Breaking Bad and Dexter - complicates this approach as their main male characters do not fit the image of hegemonic masculinity but rather corresponds to a form of "geek masculinity." This type of masculinity is defined with these two characters by their awkwardness and their lack of agency. Being beta males, the narratives developed around their characters follows their quest for patriarchal authority. While fatherhood represents one avenue towards this goal, it is their intelligence and their use of violence that eventually enable them to re-conquer white masculinity and the promise 
of power it holds. This portraying of father figures echoes the election of Donald Trump as father of the nation in a context of chaos.

The relation of America to the Native American family was the topic of the presentation by Yona Dureau (University Jean Monnet, Saint-Étienne). This dynamic was approached through the study of the life of Iron Eye Cody, an actor who played Native American characters in films and TV commercials. While born to an Italian family in Louisiana, Iron Eye Cody always claimed he was Native American and went on to represent Native nations during a meeting with the president and the pope. Arguing that psychology and psychoanalysis could be useful in completing historical and sociological approaches, Dureau tried to make sense of Iron Eye Cody's imposture. Identification to Native tribes could be traced back to experiences of persecution in his childhood as Italians were often the victims of lynchings by Louisiana's Irish population. Moreover, Iron Eye Cody's self-transformation - quite literal through the constant wearing of traditional Native American clothes - can be seen as a reflection of America's envious attitude towards the image of the Native American family. The desire to embody the envied object is followed by its destruction in order to replace it Destruction and replacement entail a sense of guilt leading to a desire of redemption: Iron Eye Cody's family involvement - he married a Native American woman and adopted many Native children - can be interpreted as a form of awkward attempt at reparation from white America.

5 Finally, Eva Maria Schörgenhuber (University of Vienna) presented her study of celebrity families and their representation in the media and on social networks. Celebrities' children have come to attract considerable media attention, which have allowed their parents to make important significant amount of money: the pictures of the new-born children get sold for top dollars to magazines and when posted on networks like Instagram, they generate myriads of "likes." The hype around celebrities' family portraits reveals the centrality of children in American cultural imagination as well as the way the child is constructed as the core of the family. In addition, the wide circulation of their pictures throughout the country displaces those children from the intimate/local sphere to that of the nation and turns them into "children of the nation." This "national family" contributes to strengthen national belonging. The relative lack of attention granted to adoptive children or families headed by same-sex parents tend to show that the biological nuclear family remains the only legitimate family unit in the eye of America.

\section{Panel 2: Family Dynamics}

6 In this second panel, the three participants offered analyses of the American family model with particular attention to race and ethnicity.

7 Eglantine Zatout (University Paris Est) scrutinized the representation of interracial couples on television. Once excluded from onscreen depictions as a result of strict guidelines like the Hays code, interracial couples have in the colorblind era become a necessary prop to prove the progressiveness of any production and to reach a larger audience. Even though interracial couples are now much more visible, they remain in the margins. More specifically, interracial couples are still excluded from the traditional family model which has been historically constructed as heterosexual, monogamous, white, and procreative. The analysis of three shows created by African- 
American screenwriter and producer Shonda Rhimes - Grey's Anatomy, Private Practice and Scandals - demonstrates that the love stories of interracial couples are usually short-lived, take place off screen, and do not lead to the creation of a family. When interracial couples do manage to get pregnant in Rhimes's shows, they find themselves facing non-viable pregnancies forcing them to resort to abortion. This pattern echoes racist views of miscegenation while restricting the taboo topic of abortion to interracial relationships. As procreation is usually the one attribute granting family status to a couple, interracial couples are refused the process that would normalize their union.

In the following presentation, Nicolas Raulin (EHESS) looked at the way the different waves of black migration from the South - the "Great Migration" - and their coming back to the South - the "New Great Migration" - have impacted the representation of the black family. The urban problems of poverty, crime, and squalor faced by these black migrants in the North were explained away by the recently-born field of sociology as the migration process's destructive effect on the black family. Social sciences went on to portray the black family as deviant and dysfunctional, which was seen as the cause of their inferior position. On the other hand, the reverse black migration to the South that began in the 1970s coincided with the rise of a robust black middle class that endeavors to reclaim the representation of the black family. The black magazine Ebony published many articles on the New Great Migration focusing on successful primary migrants to urban centers in the South while ignoring the waves of return migrants moving back to economically disadvantaged areas with little economic capital. Thus, the representation of the black family appears as a site of struggle revealing the different class positions of black Americans. This challenges the representation of the black community as one family - a narrative that also emerged in the 1970s as a new form of collective identification.

9 Finally, the last presentation of this panel by Anouche Der-Sarkissian (University Sorbonne Nouvelle - Paris 3) tackled the American-Armenian diaspora in the United States. Based on the field study she conducted in Los Angeles - the city with the largest Armenian population outside of the Armenian capital itself - her qualitative analysis demonstrates the importance of the family in migration and in the construction of ethnic communities through the process of "chain migration." Indeed, when it comes to migration policies, blood ties will usually facilitate the migrating process for foreigners even if the legal family model is narrowly defined as nuclear and heterosexual. Relying on interviews and observations, her research made apparent that the family unit for Armenian migrants was both a site of support and conflict, both a tool for and an impediment to integration. While the community of co-ethnics will allow for the preservation of cultural practices from the home country, scholars have usually pointed out the inter-generational conflicts that can arise between primary migrants and their offspring. However, the qualitative approach adopted by DerSarkissian complicates this reasoning which tends to present the culture of the home country as conservative and American culture as progressive. Indeed, the study of the Armenian community of Los Angeles reveals how the family unit can turn into a site of activism as relatives unite in order to improve their living conditions: families will play a crucial role, for example, in creating schools for their children. 


\section{Panel 3: Surviving Family}

10 For the first panel of the second day, the presentations looked at the survival of family motifs in works offering subversion of various norms, whether social or fictional.

11 The panel opened with a presentation by Yvonne-Marie Rogez (University Paris 2 Panthéon-Assas) on the theme of the family in the zombie series Fear the Walking Dead. Despite a post-apocalyptic setting filled with brain-eating zombies, the show is centered around traditional family values, namely that of the nuclear family. Indeed, far from subverting conventional norms regarding blood ties, the story line follows the fate of one white middle class family whose reunification functions as a narrative device: the stakes in seeing the family together again eventually overshadows the presence of zombies. Similarly, characters who do not belong to a family unit are not given any proper story line. Such a portrayal of the family is not representative of typical zombie films or series where the potential destruction of humanity usually implies a redefinition of traditional concepts. This is not a random decision: the production of Fear the Walking Dead aimed at reaching an audience broader than the usual zombie fans and that is precisely the function of the traditional family. This shows, once again, the centrality of the family in American life: while producers do not see any problem in showing blood-covered zombies to their audience, they do not consider their viewers ready to witness the erosion of the traditional family.

Afterwards, Saloua Karoui-Elounelli (École Normale Supérieure de Tunis) talked about the subversion of the family model in metafictional novels through the use of irony, satire and the theme of suicide. Focusing on three works - E. L. Doctorow's The Book of Daniel, John Hawkes's Second Skin and John Gardner's October Light - her presentation explored the metafictional novel's tendency to critique traditional forms of literary realism through an ironic investment in the family romance. Literary paradigms such as the oedipal theme, domestic fiction or historical fiction are deliberately perverted through the use of comic elements, which eventually satirizes and questions family values. Likewise, the theme of suicide marks a turning point in these three works, not so much for the traumatic aspect of it but rather for the potential re-construction of the family story it entails for the characters. Telling the story of their family is indeed presented for them as an act of survival in the face of a traumatic event. It emphasizes the self-reflexive quality of the metafictional novel and the power of storytelling as a gesture of survival.

\section{Panel 4: Keynote Address}

13 Keynote speaker Mette Sandbye (University of Copenhagen) gave a presentation about the family photo album. How can one understand its role as both an object of banal conformity and emotional value? The family photo album emerges in the modern age of industrialization and functions as a proof of the good life for the bourgeois family while allowing relatives to create their own memory and myths around rituals and images. The Kodak company took the lead in the mass development of the camera as an everyday affair accessible to middle class families. Their advertising campaigns epitomized the bridging of the private sphere - the album traces families' genealogy and the public sphere as the images used by the company constructed a general iconography of the good American family life on a national scale. As a result, even 
when the family photo album can be seen as an intimate and personal archive of one given family, most family pictures look the same from one family to another. Yet the family photo album can be deformed in order to tell other stories, namely narratives of loss and trauma, i.e. the other side of modernity. This is for example what photographer David Wham did by using his photo album to narrate the erosion of his marriage and the loss of his child's custody. Relating the failure of his union and the absence of his child with Lyndon B. Johnson' Vietnam policies, his work shows that the family album can function as a counter-narrative to the representation of the modern middle-class nuclear family of America.

\section{Panel 5: Family Romance}

14 The representation of the family in post-modern literature was at the core of the second panel of the day.

Bastien Meresse (Paris) offered an analysis of family patterns in Thomas Pynchon's Bleeding Edge released in 2013. In this work, the family bears witness to the impact of 9/11 on New York City and the United States, as the author's tackling of the 2001 terrorist attacks marks his return to the family novel. More specifically, the novel explores the indoctrination of children under parental pressure, which echoes Pynchon's early short story The Secret Integration (1964), where children cross the racial line and find themselves in the racist world of their parents. In a similar pattern but in the early 2000s, children are faced with yet another threat: that of technologies invading the private space of the home and the bedroom (through computers and video games for example). Pynchon denounces the use of those technologies as means to recruit a cyber army among the ranks of "script kiddies" i.e. self-taught juvenile hackers. Escaping the control of both the dictatorial father and the state requires running away from the father rather than killing him. It is in this light that the genre of the family novel chosen by Pynchon can be understood: in a world disintegrating with the debris of the twin towers, the family unit represents the last place to hide.

The following presentation by Béatrice Pire (University Sorbonne Nouvelle - Paris 3) looks at the role of the family in novels by second-generation post-modernists such as Johnathan Franzen, David Foster Wallace, or Rick Moody. Resorting to a family metaphor, the first generation of post-modernists is presented as the authors who virtually deconstructed every aspect of the novel, leaving their descendants in a field of ruins. Far from euphorically celebrating this vast deconstruction, those secondgeneration authors turn to the family as a means to cope with the angst of being orphans and seeing the traditional family eroded. In a world where everything can be re-invented, the family remains the last bastion of certitude as one cannot choose their relatives. Hence those writers' need to tell the stories of families with an allegiance to previous generations, that of the parents but also of the grand-parents. This tendency should be seen as the reflection of a demographical and sociological trend: these authors were indeed all born in the 1960s, i.e. the decade of an important demographic growth in the United States and of an erosion of the traditional family model. 


\section{Panel 7: Family Discourses}

17 The last panel of the conference encompassed reflections on the centrality of the family in political debates.

Mokhtar Ben Barka (University of Valenciennes and of Hainaut-Cambrésis) talked about the Christian right and its rhetoric centered around the family. The Christian Right that emerged in the 1970s as a crucial political force has been defending the family and traditional family values against what they saw as assaults from feminists, pro-choice activists, or the LGBTQ+ community. Their involvement in politics dates back to what was perceived as the abuses of 1960s liberalism that destabilized the divine order they defend. Their objective is to re-christianize the country through the family and a return to the only legitimate model, that of the heterosexual nuclear family with children. Resorting to the family provides a powerful strategical tool as it can appeal to many people across social differences. This is something that the Republican party has understood since the presidential campaign of Ronald Reagan: this is the moment when the GOP began to woo those evangelical voters by promising to support the values they defend so staunchly. Even though their votes, more often than not, are given to Republican candidates, the party has actually done little to achieve their goal, especially on the constitutional level. This might change, however, as Donald Trump (who received more votes from Evangelicals than George W. Bush) did appoint a very conservative Justice to replace Antonin Scalia.

Finally, Hélène Quanquin (University of Lille) ended the conference by analyzing $19^{\text {th }}$ century feminist discourses on marriage and family. The opinion of early feminists on contemporary issues such as abortion has become a matter of controversy: pro-life and pro-choice pundits now reclaim their legacy in order to legitimize their position. This reference to history as well as the recent conversation regarding the significance of Confederate symbols indicate that the nineteenth century permeates contemporary debates in the United States. What the opposite factions reclaiming $19^{\text {th }}$ century feminist discourses miss, however, is the plurality of positions within what has been called "first wave feminism." The metaphor of the wave tends to obscure the variety of thoughts among the different movements defending women's rights. While early feminists are often described as merely interested in obtaining the right to vote, some held more radical positions, especially when it came to marriage.

\section{Conclusion on the conference}

The different talks of the two-day conference clearly revealed the ongoing relevance of the family unit in American representations and politics. If the second half of the twentieth century saw a relative erosion of the normative model of the nuclear family, this very model still permeates American society as occurrences of its survival keep surfacing in films, books, TV series and collective representations.

While the 1960s marked a turning point in the deconstruction of the ideal family model - elaborated as white, heterosexual monogamous and nuclear - many of the talks presented the resurgence of normative models as a political backlash against the socalled abuses of the decade or as a nostalgic return to a fantasized golden age in the face of national anxiety symbolized by $9 / 11$ and the economic recession. 
That being said, the presentations also emphasized the different ways in which the family is being re-invented as groups marginalized in terms of ethnicity or sexual orientation have begun to reclaim the representation of the family. The family unit still plays a central role in ensuring a positive response from the American public - whether in fiction or in political debates - which reveals a form of conservatism. Yet the broadening of the definition of what constitutes a family is also the sign of progressivism. Ultimately, the family lies in this dialectic tension between these two poles while encapsulating social and political divisions - the so-called "culture wars" within the contemporary United States.

INDEX

Subjects: Actualité de la recherche

\section{AUTHOR}

NICOLAS RAULIN

EHESS, Centre d'études nord-américaines 